\title{
Contribution to the knowledge of the Carabus Linnaeus, 1758 subgenus Microtribax Gottwald, 1982 in the North Caucasus, with description of a new subspecies (Coleoptera: Carabidae)
}

\section{К познанию подрода Microtribax Gottwald, 1982 рода Carabus Linnaeus, 1758 (Coleoptera: Carabidae) на Северном Кавказе и описание нового подвида}

\author{
D.D. Fominykh ${ }^{1}$, A.S. Zamotajlov ${ }^{2,3}$, T.A. Avtaeva ${ }^{4}$, A.Yu. Titarenko \\ А.А. Фоминых ${ }^{1}$, А.С. Замотайлов ${ }^{2,3}$, Т.А. Автаева ${ }^{4}$, А.Ю. Титаренко ${ }^{5}$ \\ ${ }^{1}$ Russian Entomological Society, Kuban Branch, Kalinin st. 13, Krasnodar 350044, Russia. E-mail: biologne@mail.ru. \\ 2 I.T. Trubilin Kuban State Agrarian University, Kalinin st. 13, Krasnodar 350044, Russia. E-mail: a_zamotajlov@mail.ru. \\ ${ }^{3}$ Adyghei State University, Pervomayskaya st. 208, Maykop 385000, Republic of Adygheya, Russia. \\ ${ }^{4}$ Kh.I. Ibragimov Complex Institute, Staropromyslovskoye shosse 12a, Grozny 364906, Chechen Republic, Russia. E-mail: avtaeva1971@mail.ru. \\ ${ }^{5}$ Publicly Traded Company "Morpho Absoloni”, Bolotnikovskaya st. 5/3, Moscow 117556, Russia. E-mail: odindva3@gmail.com. \\ 1 Русское энтомологическое общество, Кубанское отделение, ул. Калинина 13, Краснодар 350044, Россия. \\ 2 Кубанский государственный аграрный университет им. И.Т. Трубилина, ул. Калинина 13, Краснодар 350044, Россия. \\ 3 Адыгейский государственный университет, ул. Первомайская 208, Майкоп 385000, Республика Адыгея, Россия. \\ ${ }^{4}$ Комплексный научно-исследовательский институт им. Х.И. Ибрагимова, Российская Академия наук, Старопромысловское \\ шоссе 21a, Грозный 364051, Чеченская Республика, Россия. \\ 5 OAO “Morpho Absoloni”, ул. Болотниковская 5/3, Москва 117556, Россия.
}

KEY WORDS: Coleoptera, Carabidae, Carabus, Microtribax, North Caucasus, distribution, ecology, iconography, a new subspecies, a new synonym.

КЛЮЧЕВЫЕ СЛОВА: Coleoptera, Carabidae, Carabus, Microtribax, Северный Кавказ, распространение, экология, иконография, новый подвид, новый синоним.

ABSTRACT. On the basis of material collected by the authors in 2015-2018 in the central and eastern parts of the North Caucasus, as well as in the north-eastern part of Georgia, new data are provided on nomenclature, taxonomy, distribution, and ecology of the genus Carabus Linnaeus, 1758 subgenus Microtribax Gottwald, 1982. A new subspecies C. nothus sharoiensis ssp.n. from the vicinities of the village Sharoy in the interfluve of rivers Argun and Sharoargun is described. C. kasakorum scintillans Rapuzzi, 2018, syn.n. is synonymized with $C$. kasakorum tschetschenicus Semenov, 1896, C. kasakorum daghestanicola Rapuzzi, 2018 is assigned to C. nothus Adams, 1817, systematic affiliation of C. planipennis abdurakhmanovi Belousov, 1995, nom.nud. is discussed.

РЕЗЮМЕ. На основе материала, собранного авторами в 2015-2018 гг. в центральной и восточной частях Северного Кавказа, а также в северо-восточной части Грузии, приводятся новые данные по номенклатуре, систематике, распространению и эко- логии подрода Microtribax Gottwald, 1982 рода Carabus Linnaeus, 1758. Описывается новый подвид C. nothus sharoiensis ssp.n. из окрестностей села Шарой в междуречье рек Аргун и Шароаргун. $C$. kasakorum scintillans Rapuzzi, 2018, syn.n. синонимизирован с C. kasakorum tschetschenicus Semenov, 1896, C. kasakorum daghestanicola Rapuzzi, 2018 отнесен к C. nothus Adams, 1817, обсуждается систематическая принадлежность C. planipennis abdurakhmanovi Belousov, 1995, nom.nud.

\section{Introduction}

The subgenus Microtribax Gottwald, 1982 has been established to house 6 species earlier attributed by Gottwald [1980] to the "nothus-Gruppe" of Tribax Fischer von Waldheim, 1817. This subgenus was also accepted by Kryzhanovskij et al. [1995], Bousquet et al. [2003], Retezár [2015], and many other authors. Břzina et al. [2017] treated the Microtribax attributed

How to cite this article: Fominykh D.D., Zamotajlov A.S., Avtaeva T.A., Titarenko A.Yu. 2019. Contribution to the knowledge of the Carabus Linnaeus, 1758 subgenus Microtribax Gottwald, 1982 in the North Caucasus, with description of a new subspecies (Coleoptera: Carabidae) // Russian Entomol. J. Vol.28. No.2. P.125 -137. doi: 10.15298/rusentj.28.2.03 
species within the subgenus Tribax, following Deuve's concept [2004] of the genus Carabus subdivisions, this approach being justified in the same book above [Huber et al., 2017]. Unfortunately Osawa et al. [2004] did not record the Microtribax-species in their book on the molecular phylogeny of Carabus, thus their probable taxonomic status seems to remain unresolved till now. We follow hereafter the system of the genus Carabus accepted by Makarov et al. in their "Taxonomical list of ground beetles (Carabidae) of Russia" [2013]. Makarov et al. [2018] and Brrezina et al. [2017] recognized two species of the group in question in the North Caucasus, namely C. nothus Adams, 1817 and C. kasakorum Semenov, 1896, some aspects of their distribution, taxonomy, and ecology are discussed below.

Material has been collected mainly by the authors in 2015-2018 during expeditions to the North Ossetia, Ingushetia, Chechnya, as well as to the north-eastern part of Georgia, adjoining these territories of the North Caucasus. Comparison of the external morphological characters and male genitalia structure of the populations studied testifies to subspecificity of the ones distributed at the mountain masses of Skalistyi Mt. Range between valleys of Argun and Sharoargun, a new taxon erected to include them is described below. We have to note also, that one of the subspecies recently described by Rapuzzi [2018], C. kasakorum scintillans Rapuzzi, 2018, actually originates from the type locality of C. kasakorum tschetschenicus Semenov, 1896, namely Mt. Stolovaya (= Matkhokh, or Matchoch), both taxa being identical morphologically and representing subjective synonyms. Another subspecies described in the same paper, C. kasakorum daghestanicola Rapuzzi, 2018, basing on its main morphological features, particularly endophallus structure, should be attributed to different species $C$. nothus. According to available material, distribution range of C. kasakorum reaches the left bank of Argun in the east and does not cross this river valley, further eastwards, at the northern macroslopes of the Greater Caucasus, it is substituted by $C$. nothus Adams, 1817 (Fig. 1). The unpublished name "C. planipennis abdurakhmanovi" [Kryzhanovskij et al., 1995] should be attributed to C. nothus daghestanicola too.

Standard methods were applied for treating the material. Endophallus inflation methods generally follow Janovska et al. [2013]. Pictures of the habitus and male genitalia were taken using a Canon EOS 5D, Mark III camera with a Canon MP-E $65 \mathrm{~mm}$ macro photo lens. External characters were studied with the LZOS MBS10 and PZO MST-131 stereoscopes. Digital photographs of the morphological structures were taken by Dr. K. Makarov, live and biotope photographs - by the

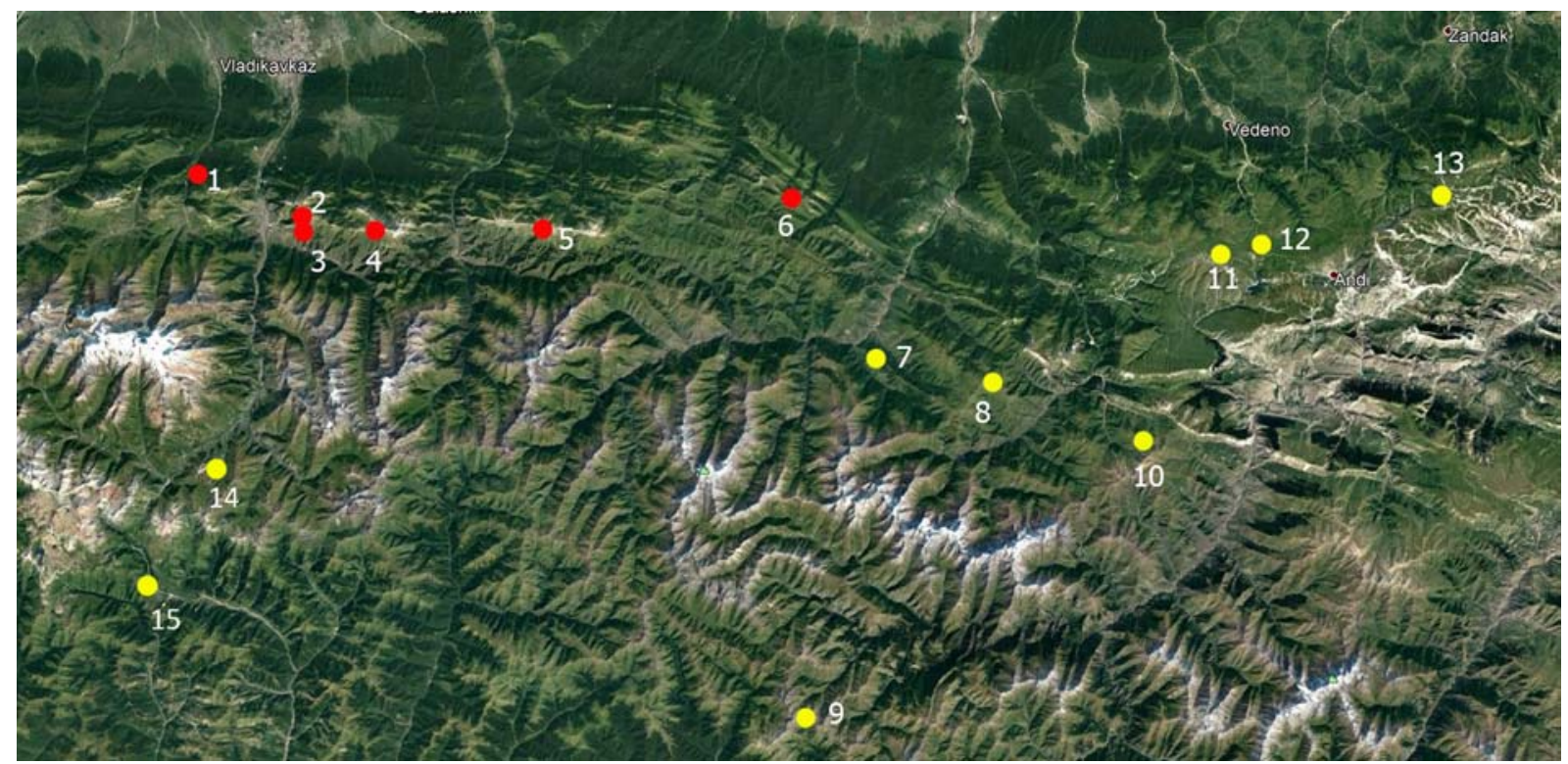

Fig. 1. Studied localities of the Carabus subgenus Microtribax in the central and eastern parts of the North and South Caucasus: 1 C. kasakorum kasakorum; 2-6-C. kasakorum tschetschenicus; 7-8 - C. nothus sharoiensis ssp. n.; $9-$ C. nothus planipennis; 10-13 - C. nothus daghestanicola; 14-15-C. nothus nothus; 1 - Mt. Fetkhuz, 900 m; 2 - Mt. Stolovaya, 2800 m; 3 - Mt. Stolovaya, 2200 m; 4 - Mt. Giryag, 2360 m; 5 - Mt. Khakhalgi, $2500 \mathrm{~m} ; 6$ - Mt. Ekkyrkort, $2230 \mathrm{~m} ; 7$ - Veduchi environs, 1200-1400 m; 8 —Sharoy environs, 2400 m; 9 - Pass Abano, 3000-3100 m; 10 - Mt. Zainkort, 2300-2800 m; 11 - Lake Kazenoy-Am vicinities, 2350 m; 12 Pass Kharami (type locality); 13 - Andiyskiy Mt. Range, $2350 \mathrm{~m} ; 14$ - Sioni environs, $2450 \mathrm{~m} ; 15$ - Zemo-Mleta environs, $1730 \mathrm{~m}$.

Рис. 1. Изученное распространение подрода Microtribax рода Carabus в центральной и восточной частях Северного Кавказа и Закавказья: $1-$ C. kasakorum kasakorum; 2-6-C. kasakorum tschetschenicus; 7-8 - C. nothus sharoiensis ssp. n.; 9 - C. nothus planipennis; 10-13 - C. nothus daghestanicola; 1 - г. Фетхуз, 900 м над ур. м.; 2 - г. Столовая, 2800 м над ур. м.; 3 - г. Столовая, 2200 м над ур. м.; 4 - г. Гиряг, 2360 м над ур. м.; 5 - г. Хахалги, 2500 м над ур. м.; 6 - г. Эккыркорт, 2230 м над ур. м.; 7 - окр. Ведучи, 1200-1400 м над ур. м.; 8 - окр. Шарой, 2400 м над ур. м.; 9 - пер. Абано, 3000-3100 м над ур. м.; 10 - г. Заинкорт, 23002800 м над ур. м.; 11 - окр. оз. Казеной-ам, 2350 м над ур. м.; 12 - пер. Харами (типовое местонахождение); 13 - Андийский хр., 2350 м над ур. м.; 14 - окр. Сиони, 2450 м над ур. м.; 15 - окр. Земо-Млета, 1730 м над ур. м. 
authors. Measurements were taken using the stereoscopes with an ocular-micrometer as follows: general body length (GBL), measured from the tips of mandibles to the elytral apex; standard body length (SBL), measured from the anterior margin of the clypeus to the elytral apex; head width (HW), measured as the maximum linear distance across the head, including the compound eyes; maximum width of pronotum measured at its broadest point (PW); minimum width of pronotum $(\mathrm{PB})$, measured at its narrowest point near the hind angles; length of pronotum (PL), measured along its median line; length of elytra (EL), measured from the basal border in the scutellar region to the apex of the sutural angle; maximum width of the elytra (EW) measured at their broadest point. The following ratios were also measured: PW/HW; PW/PL; PW/PB; EW/P; EL/ EW. Most of measurements and indices are given in a separate table (Tables 1-2) to facilitate comparisons between $C$. nothus sharoiensis ssp.n. and $C$. nothus daghestanicola populations. Homology of the morphological structures of endophallus are depicted in the Fig. 2 . Their names generally follow those given by Shilenkov [1996], with some modifications and additions already applied in our previous papers [Fominykh et al., 2016, etc.].

The following acronyms are used for the depositories of the specimens examined: ZISP - Zoological Institute of the Russian Academy of Sciences (St. Petersburg, Russia); ZMMU - Zoological Museum of the Moscow State University (Moscow, Russia); MPSU -
Moscow Pedagogical State University, Chair of Zoology and Ecology (Moscow, Russia); CFDD — Private collection of D.D. Fominykh (Krasnodar, Russia); CTAY - Private collection of A.Yu. Titarenko (Moscow, Russia); CZAM - Private collection of A.S. Zamotajlov (Krasnodar, Russia); CATA — Private collection of T.A. Avtaeva (Grozny, Russia).

\section{Results}

\section{Carabus (Microtribax) nothus daghestanicola Rapuzzi, 2018}

Figs 1, 11-18, 23-26, 38-41, 45-46, 49-50.

Rapuzzi, 2018: 408 (Carabus kasakorum ssp.). Carabus planipennis abdurakhmanovi in. litt.: Kryzhanovskij et al., 1995: 55, nom.nud.; Abdurakhmanov G., Davydova, 1999: 9; Abdurakhmanov V., 2012: 102; Erzhapova, 2012: 106; Fominykh, Zamotajlov, 2017: 527. Carabus abdurakhmanovi in. litt.: Abdurakhmanov et al., 2007: 198, nom.nud.; Abdurakhmanov, 2009: 297; Avtaeva, Kushalieva, 2017: 9

MATERIAL. $1780^{7} 0^{7}, 184$ 우 (ZMMU, MPSU, CFDD, CTAY, CZAM, CATA), Russia, North Caucasus, Chechnya, Andiyskiy Mt. Range upper river Benoyasy, N slope of Mt. Dzhaldyr, N 42 $51^{\prime} 59.90^{\prime \prime}, \mathrm{E} 46^{\circ} 26^{\prime} 00.50^{\prime \prime}, \mathrm{h}=2350 \mathrm{~m}, 27$.V-14.VII.2018, D.Fominykh, T. Avtaeva, Sh. Kushalieva leg.; $70^{7} 0^{7}, 13$ 우 (CFDD, CTAY, CZAM, CATA), Chechnya, Kashkerlam Mt. Range near Lake Kazenoy-Am, N slope of Mt. Khachkar, N 42॰47'52.57", E

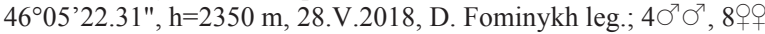
(CFDD, CTAY, CZAM, CATA), Chechnya, N slopes of Snegovoy Mt. Range, $5.5 \mathrm{~km}$ SE of Kenkhi upper river Kenkhi, N slopes of Mt.

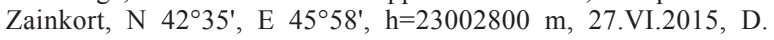
Fominykh leg.

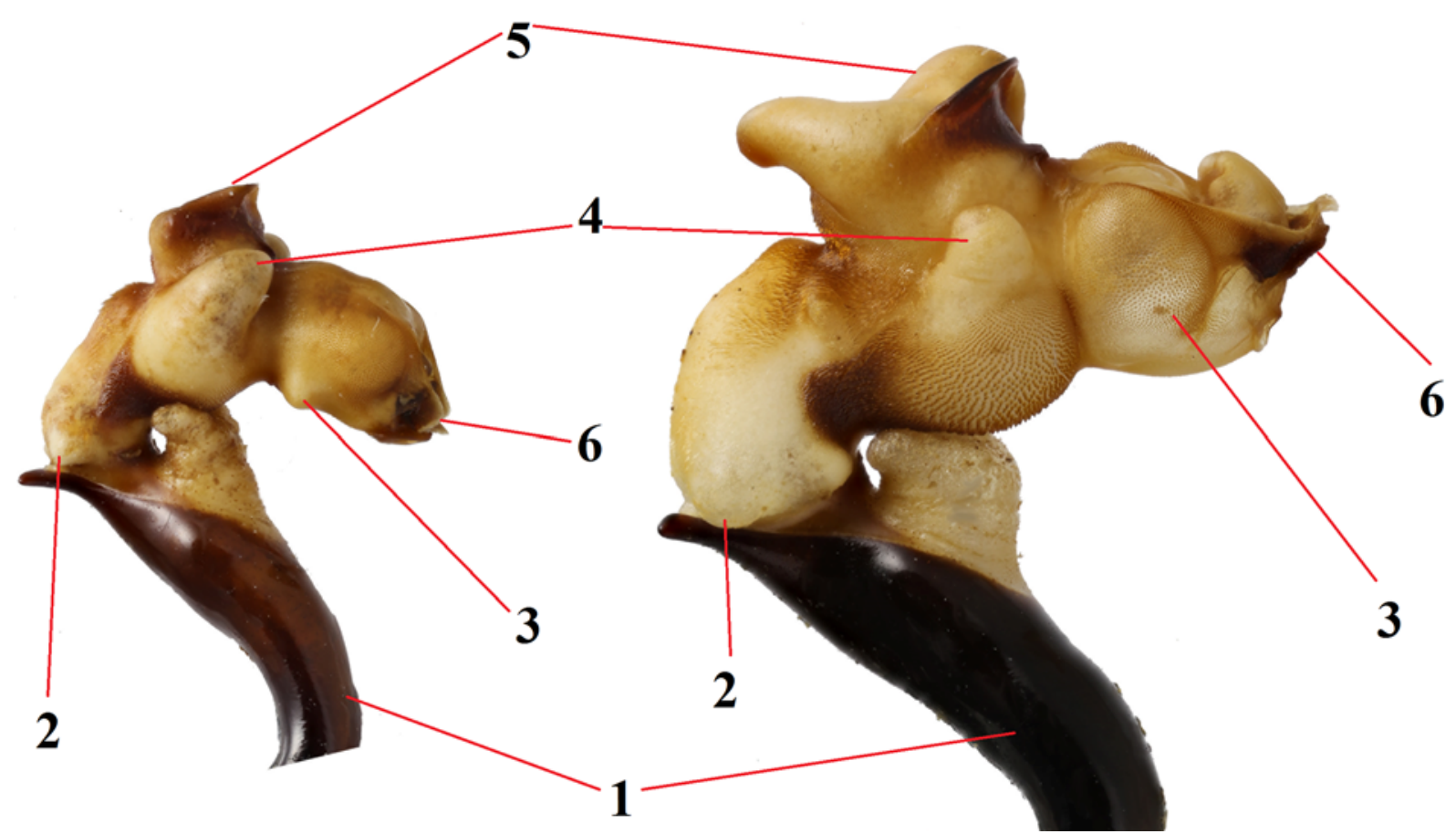

Fig. 2. Apical portion of aedeagus and homology of the fully inflated endophallus preparation in the subgenus Microtribax: 1 - tube of penis; 2 - basiolateral lobe; 3 - dorsoapical lobe; 4 - mediolateral lobe; 5 - ventroapical lobe; 6 - aggonoporius.

Рис. 2. Вершина эдеагуса и гомология структур препарата полностью вывернутого внутреннего мешка в подроде Microtribax: 1 - трубка пениса; 2 - базилатеральная лопасть; 3 - дорзоапикальная лопасть; 4 - медиолатеральная лопасть; 5 вентроапикальная лопасть; 6 - аггонопориус. 
COMPARATIVE MATERIAL. Carabus (Microtribax) kasakorum kasakorum Semenov, 1896: $15 \sigma^{\top} \sigma^{7}$, 14우 (CFDD), Russia, North Caucasus, North Ossetia, Pastbishchnyi Mt. Range, E slopes of Fetkhuz Mt. Rane, right bank of river Gizeldon, N 4256', E 4433', h=900m, 22.V-12.VII.2016, D. Fominykh, A Zubov leg.

DISTRIBUTION. This subspecies was described from Pass Kharami in the vicinities of Lake Kazenoy-Am, we collected it $5 \mathrm{~km}$ south-westwards from the type locality, this material seems to be identical in its characters to the individuals described by Rapuzzi. "C. planipennis abdurakhmanovi' was also recorded from Kazenoy-Am vicinities and Andi-
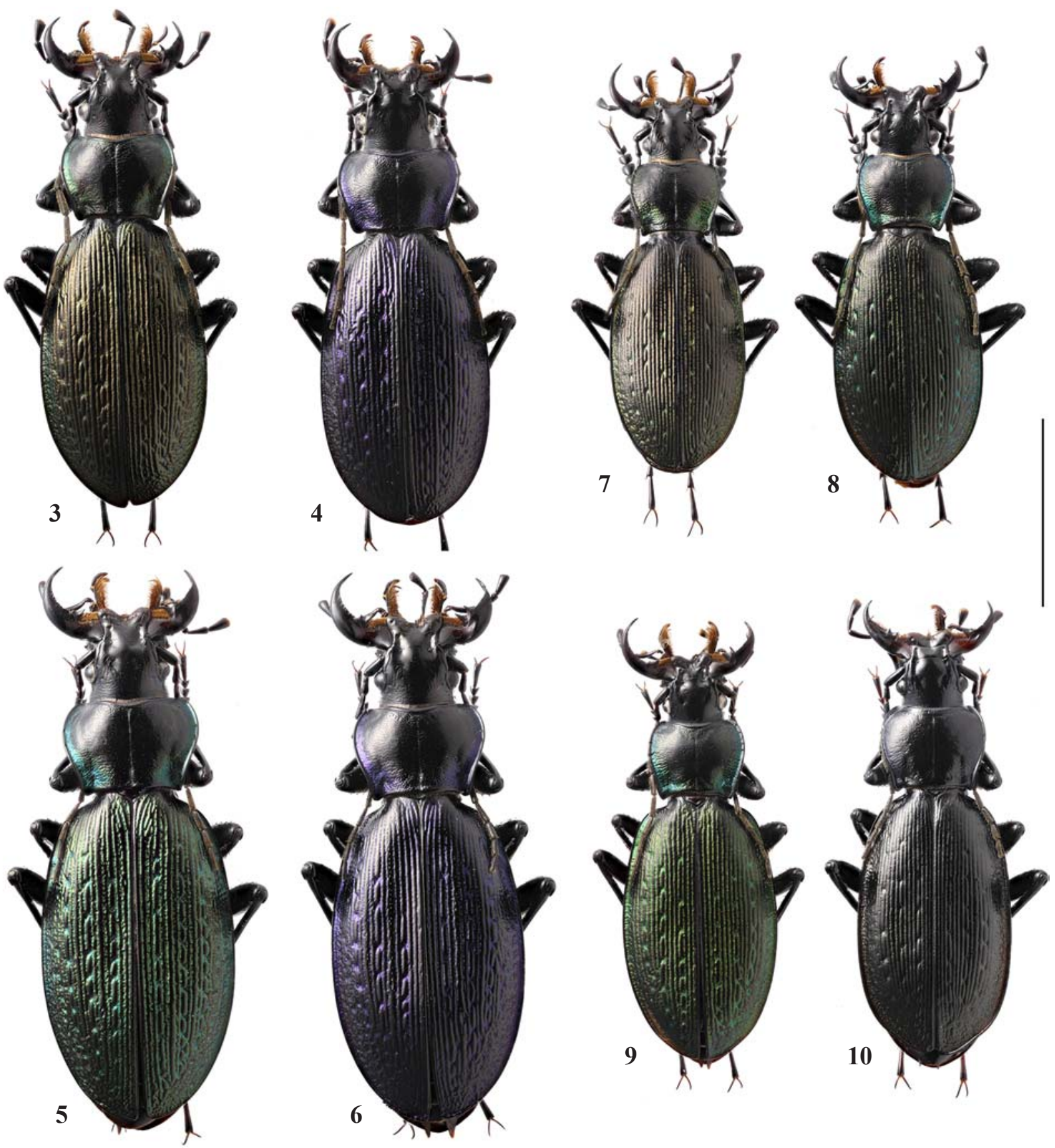

Figs 3-10. Dorsal habitus of the subgenus Microtribax: 3-6 - C. kasakorum kasakorum, Mt. Fetkhuz, 900 m; 7-10 - C. kasakorum tschetschenicus, Mt. Stolovaya, $2800 \mathrm{~m}$. Scale bar: $10.0 \mathrm{~mm}$.

Рис. 3-10. Габитус видов подрода Microtribax: 3-6 - C. kasakorum kasakorum, г. Фетхуз, 900 м над ур. м.; 7-10 — C. kasakorum tschetschenicus, г. Столовая, 2800 м над ур. м. Масштаб: 10.0 мм. yskiy Mt. Range spatially near to above listed in the material locality, so correctness of its subspecific affiliation

In general $C$. nothus daghestanicola is distributed eastwards of Sharoargun valley, at mountain masses of Skalistyi, Snegovoy, and Andiyskiy Mt. Ranges (Fig. 1), in the south it is substituted by different subspecies C. nothus planipennis ssp. n., described below.

REMARKS. This subspecies inhabits alpine zone at 2300 $2800 \mathrm{~m}$ and gravitates towards the stony hillside wastes. 
Carabus (Microtribax) nothus sharoiensis Fominykh, Zamotajlov, Avtaeva et Titarenko, ssp.n. Figs 1, 27-37, 47-48, 51 .

MATERIAL. Holotype $0^{7}$ (ZISP), Russia, North Caucasus, Chechnya, left bank of river Sharoargun, road between Sharoy and

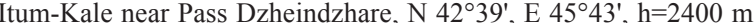
23.V.2016, D. Fominykh, A. Zubov, T. Avtaeva, Sh. Kushalieva leg.; Paratypes: $270^{7} \sigma^{7}, 25$ 우 (CFDD, CTAY, CZAM, CATA), same data as holotype; $340^{7} 0^{7}$, 21 우 (ZMMU, MPSU, CFDD, CTAY, CZAM, CATA), same locality, but 23.V-12.IX.2016, D Fominykh, A. Zubov, T. Avtaeva, Sh. Kushalieva leg.; $70^{7} 0^{7}, 3$ (CFDD), Chechnya, Vedutchi env., Khacha-Royduk Mt. Range, $\mathrm{h}=1200-1400 \mathrm{~m}$, VI.1990, G. Abdurakhmanov.
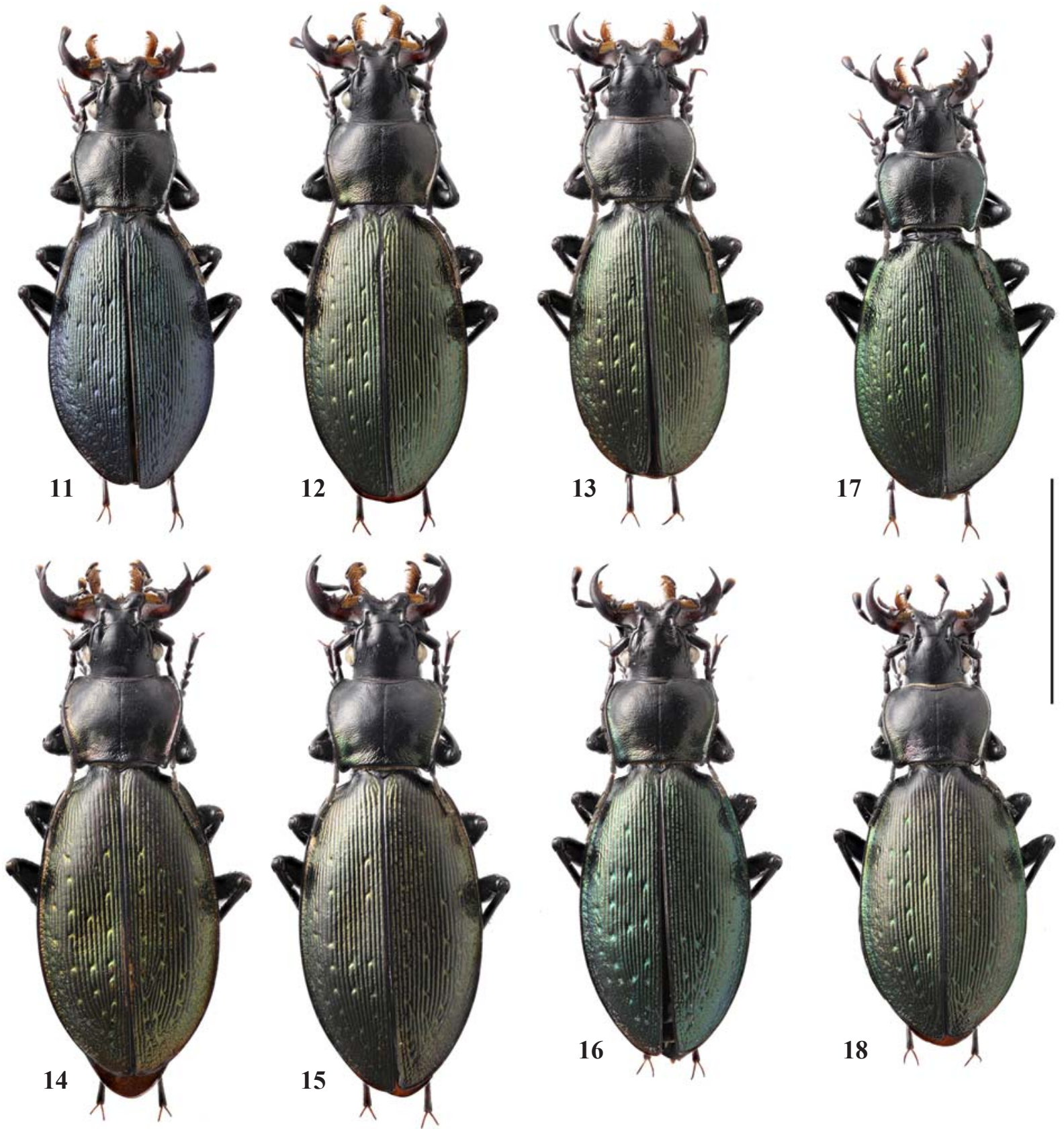

Figs 11-18. Dorsal habitus of the subgenus Microtribax: 11-16 - C nothus daghestanicola, Andiyskiy Mt. Range, 2350 m; 17-18 C. nothus daghestanicola, Mt. Zainkort, 2300-2800 m. Scale bar: $10.0 \mathrm{~mm}$

Рис. 11-18. Габитус сверху подрода Microtribax: 11-16 - C. nothus daghestanicola, Андийский хр., 2350 м над ур. м.; 17-18 C. nothus daghestanicola, г. Заинкорт, 2300-2800 м над ур. м. Масштаб: 10.0 мм. 
$26.3 \mathrm{~mm}, \mathrm{SBL}=19.2-23.3 \mathrm{~mm}$ in both sexes. Underside black, dorsum with metallic luster similar both in males and females, head black, pronotum black on disk, lateral sides with metallic coloration, elytra with bright metallic green or bronze luster, legs, antennae, and mandibles black, with faint brownish tint. Head not inflated, with nearly equal length and width, $\mathrm{HL}=3.0-3.7 \mathrm{~mm}$ in males, $3.3-4.3 \mathrm{~mm}$ in females, $\mathrm{HW}=3.4-3.7 \mathrm{~mm}$ in males, $3.5-4.8 \mathrm{~mm}$ in females; neck punctate, surface with coarse rugosity near eyes; mandibles elongate; antennae reaching one-third to middle of elytra. Pronotum nearly rectangular, sides with very faint sinuation before base, $\mathrm{PW}=3.4-3.7 \mathrm{~mm}$ in males, $4.5-6.1 \mathrm{~mm}$ in females, $\mathrm{PB}=3.5-4.0 \mathrm{~mm}$ in males, $3.3-4.5 \mathrm{~mm}$ in females,
$\mathrm{PL}=3.2-3.9 \mathrm{~mm}$ in males, $3.5-4.1 \mathrm{~mm}$ in females, $\mathrm{PW} / \mathrm{HW}$ $=1.2-1.5$ in both sexes, $\mathrm{PW} / \mathrm{PL}=1.3-1.6$ in both sexes, $\mathrm{PW} /$ $\mathrm{PB}=1.2-1.4$ in both sexes; hind angles faintly protruding posteriorly; disk completely punctate, punctation more coarse at sides and base. Legs moderately long. Elytra faintly convex, ovate, somewhat elongate, $\mathrm{EW} / \mathrm{PW}=1.4-1.9$ in both sexes; $\mathrm{EL}=12.0-13.5 \mathrm{~mm}$ in males, $12.9-15.6 \mathrm{~mm}$ in females, $\mathrm{EW}=3.44 .4 \mathrm{~mm}$ in males, $3.5-4.8 \mathrm{~mm}$ in females, $\mathrm{EL} / \mathrm{EW}=1.4-1.8$ in both sexes; elytral sculpture pronounced, 3 rows of impressions are distinguishable, these punctures regularly covering entire elytral surface.

Aedeagus faintly bent basally, apical lamella hardly protruding (Figs 35-37). Endophallus with strongly developed
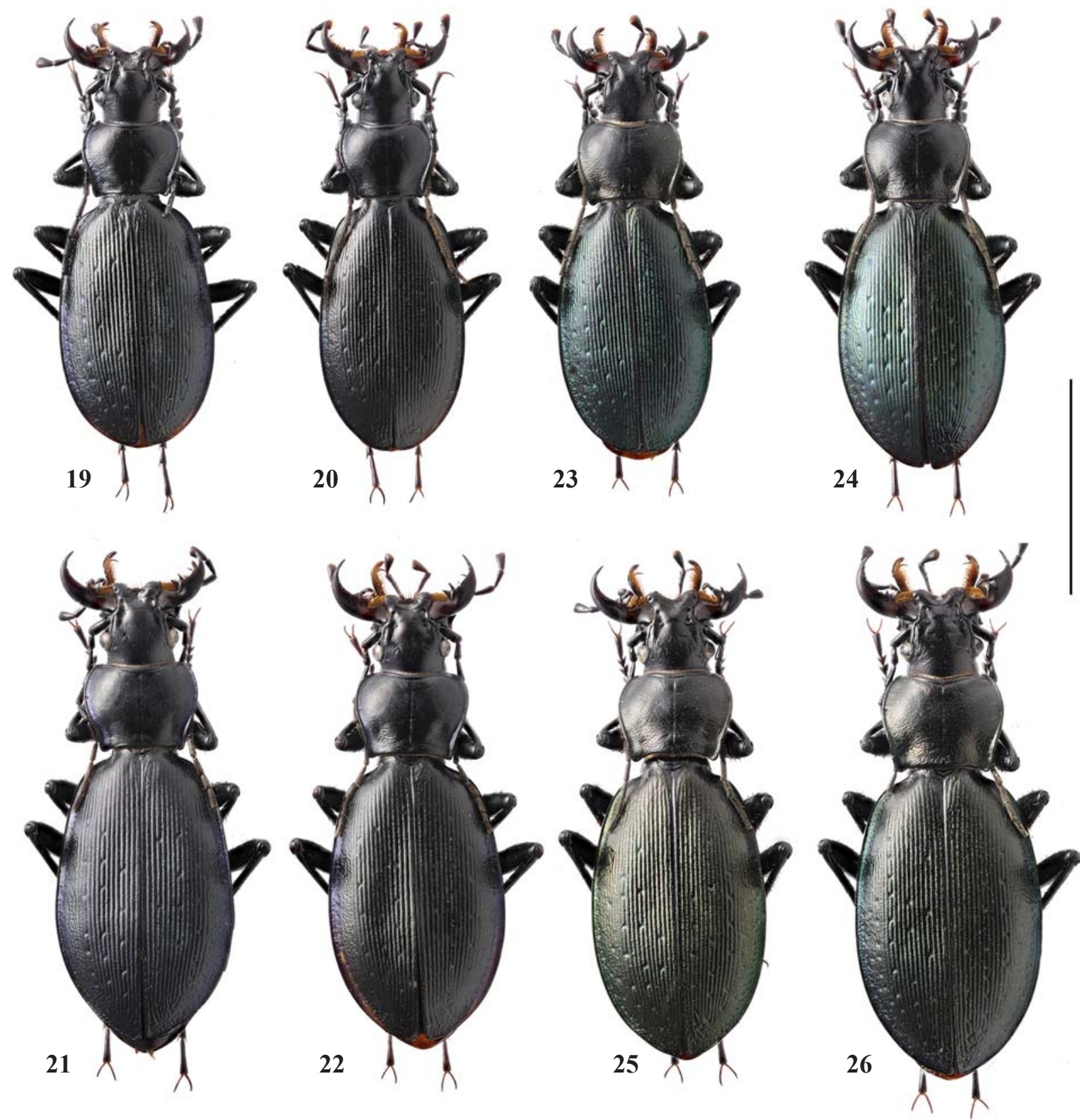

Figs 19-26. Dorsal habitus of the subgenus Microtribax: 19-22 - C. nothus planipennis, Pass Abano, 3000-3100 m; 23-26 - C. nothus daghestanicola, Lake Kazenoy-Am vicinities, $2350 \mathrm{~m}$. Scale bar: $10.0 \mathrm{~mm}$.

Рис. 19-26. Габитус сверху подрода Microtribax: 19-22 - C. nothus planipennis, пер. Абано, 3000-3100 м над ур. м.; 23-26 C. nothus daghestanicola, окр. оз. Казеной-Ам, 2350 м над ур. м. Масштаб: 10.0 мм. 
mediolateral and ventroapical lobes, basiolateral and dorsoapical lobes less prominent, aggonoporius small.

DIFFERENTIAL DIAGNOSIS AND REMARKS. A new subspecies reliably differs from C. kasakorum in the male genitalia structure. It is distinguishable from the other known subspecies of $C$. nothus by constantly brighter dorsal coloration, not characteristic for them. From the most close morphologically subspecies $C$. nothus daghestanicola it differs also in more depressed elytra and fainter protruding posteriorly hind angles of pronotum.
DISTRIBUTION AND HABITAT. A new subspecies populates mountain masses of Skalistyi Mt. Range in the interfluve of Argun and Sharoargun rivers, it inhabits meadows at $1200-2400 \mathrm{~m}$ and prefers stony sites. The adults are active from the end of May, beginning with the snow melting. Following Carabus forms occur together with this subspecies: C. (Pachycarabus) staehlini Adams, 1817, C. (Tomocarabus) convexus Fabricius, 1775, C. (Sphodristocarabus) adamsi Adams, 1817, C. (Cechenochilus) boeberi Adams, 1817, C. (Tribax) osseticus Adams, 1817, C. (Eu-
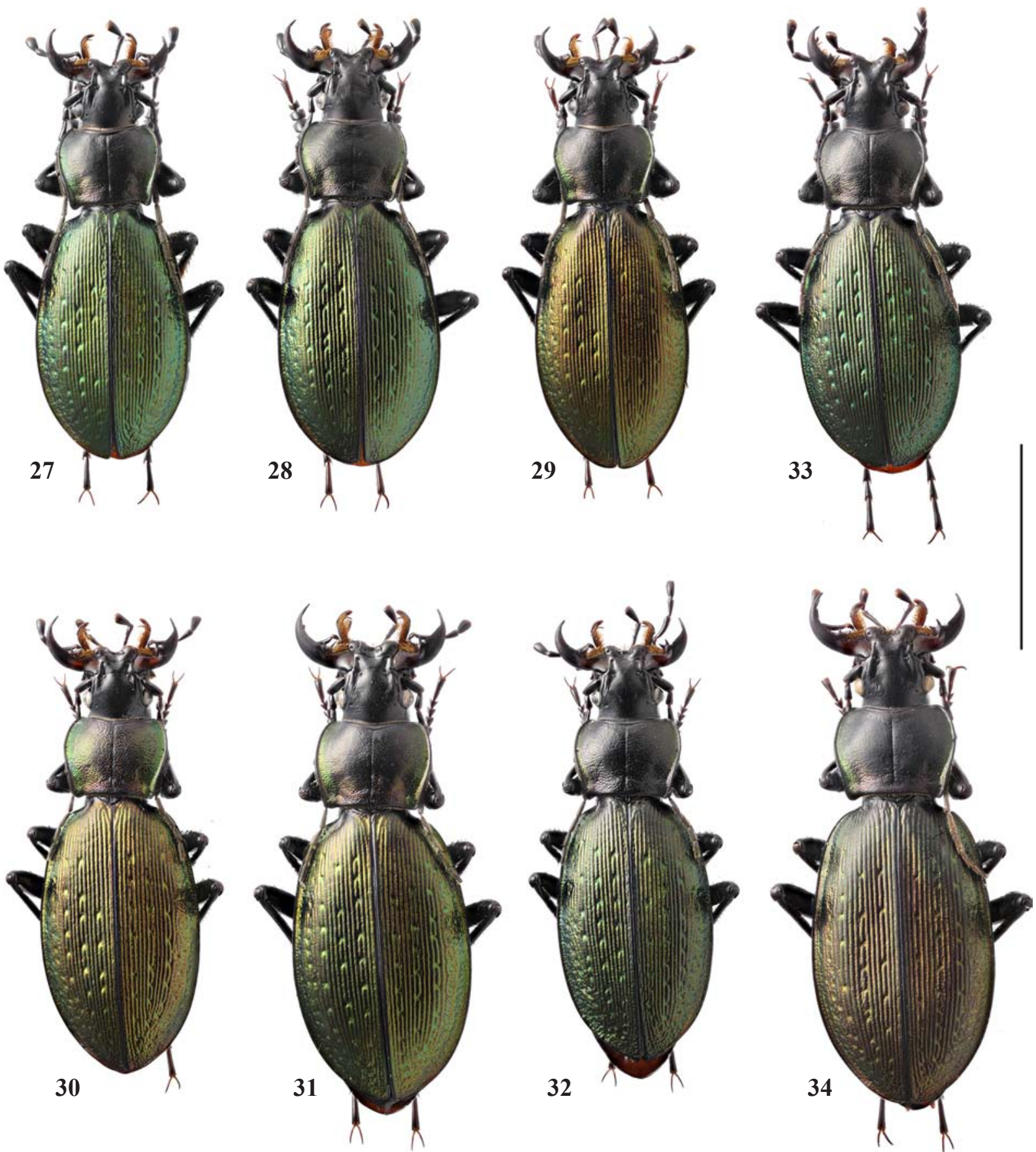

Figs 27-34. Dorsal habitus of the subgenus Microtribax: 27-32 - C. nothus sharoiensis ssp. n., Sharoy environs, 2400 m; $33-34-$ C. nothus sharoiensis ssp. n., Veduchi environs, 1200-1400 m. Scale bar: $10.0 \mathrm{~mm}$.

Рис. 27-34. Габитус видов подрода Microtribax: 27-32 - C. nothus sharoiensis ssp. n., окр. пос. Шарой, 2400 м над ур. м.; 33$34-C$. nothus sharoiensis ssp. n., окр. пос. Ведучи, 1200-1400 м над ур. м. Масштаб: 10.0 мм. 


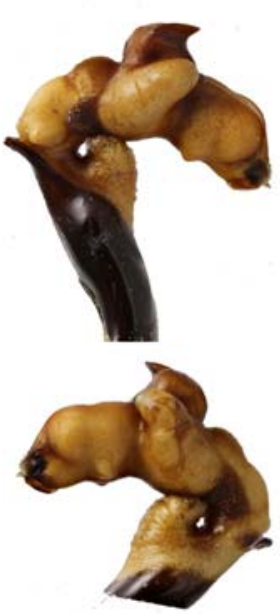

35

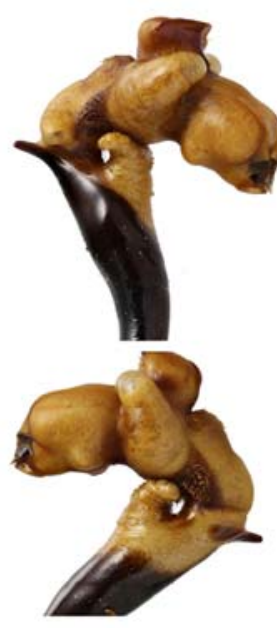

36

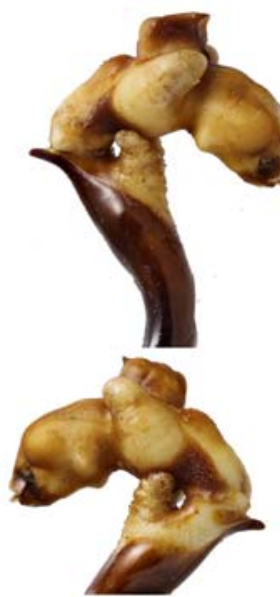

37

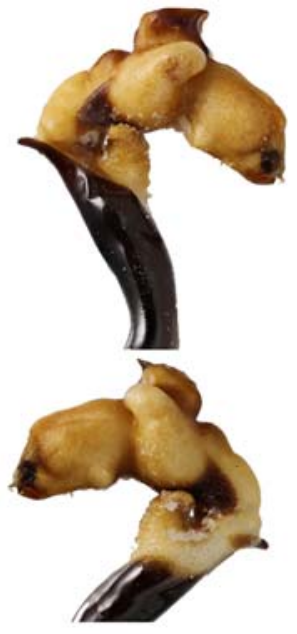

38

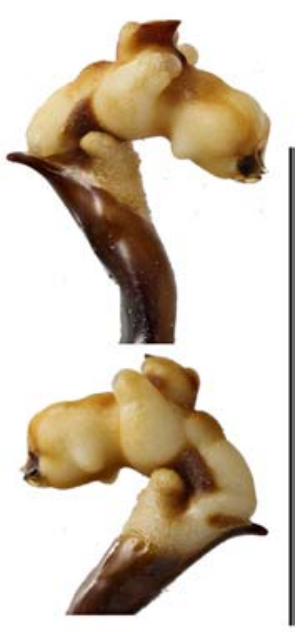

39

Figs 35-39. Apical portion of aedeagus and fully inflated endophallus preparation of the subgenus Microtribax, right lateral view on top, left lateral view below: 35-36-C. nothus sharoiensis ssp. n., Sharoy environs, $2400 \mathrm{~m} ; 37-$ C. nothus sharoiensis ssp. n., Veduchi environs, 1200-1400 m; 38 - C. nothus daghestanicola, Kenkhi env., 2300 m.; 39 - C. nothus daghestanicola, Mt. Zainkort, $2800 \mathrm{~m}$. Scale bar: $10.0 \mathrm{~mm}$.

Рис. 35-39. Вершина эдеагуса и препарат полностью вывернутого внутреннего мешка подрода Microtribax, вверху — сбоку справа, внизу - сбоку слева: 35-36-C. nothus sharoiensis ssp. n., окр. пос. Шарой, 2400 м над ур. м.; $37-$ C. nothus sharoiensis ssp. n., окр. пос. Ведучи, 1200-1400 м над ур. м.; $38-$ C. nothus daghestanicola, окр. Кенхи, 2300 м над ур. м.; $39-$ C. nothus daghestanicola, г. Заинкорт, 2800 м над ур. м. Масштаб: 10.0 мм.
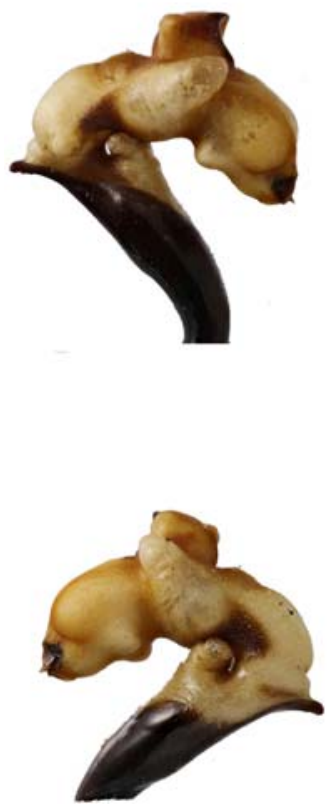

40
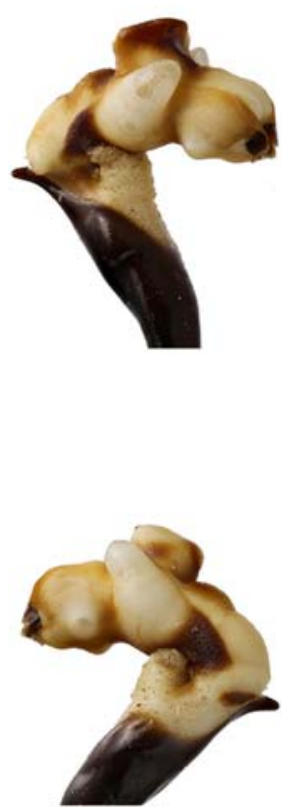

41
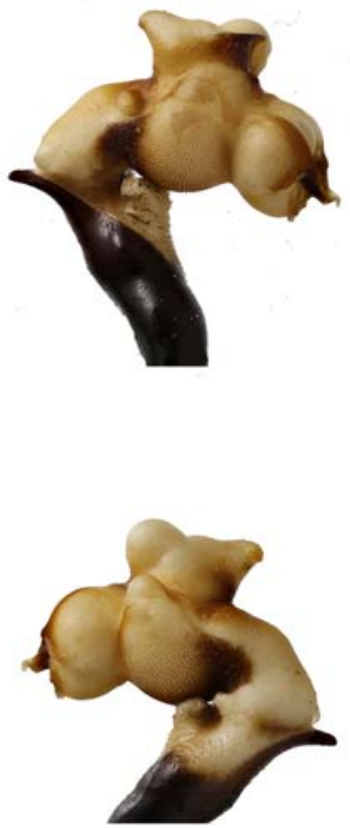

42
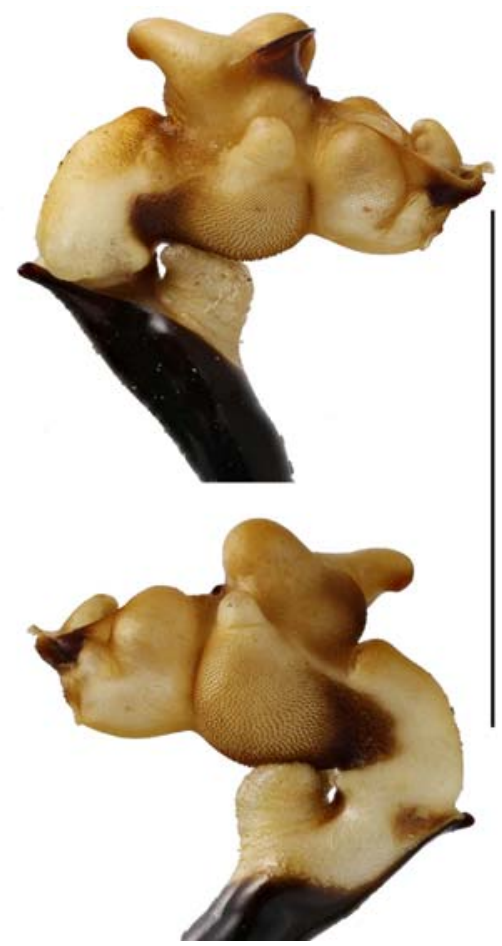

43

Figs 40-43. Apical portion of aedeagus and fully inflated endophallus preparation of the subgenus Microtribax, right lateral view on top, left lateral view below: $40-$ C. nothus daghestanicola, Andiyskiy Mt. Range, 2350 m; 41 - C. nothus daghestanicola, Lake Kazenoy-Am vicinities, 2350 m; 42 - C. kasakorum tschetschenicus, Mt. Stolovaya, 2800 m; 43 - C. kasakorum kasakorum, Mt. Fetkhuz, 900 m. Scale bar: $10.0 \mathrm{~mm}$.

Рис. 40-43. Вершина эдеагуса и препарат полностью вывернутого внутреннего мешка подрода Microtribax, вверху — сбоку справа, внизу - сбоку слева: $40-$ C. nothus daghestanicola, Андийский хр., 2350 м над ур. м.; $41-$ C. nothus daghestanicola, окр. оз. Казеной-Ам, 2350 м над ур. м.; 42 - C. kasakorum tschetschenicus, г. Столовая, 2800 м над ур. м.; 43 - C. kasakorum kasakorum, г. Фетхуз, 900 м над ур. м. Масштаб: 10.0 мм. 

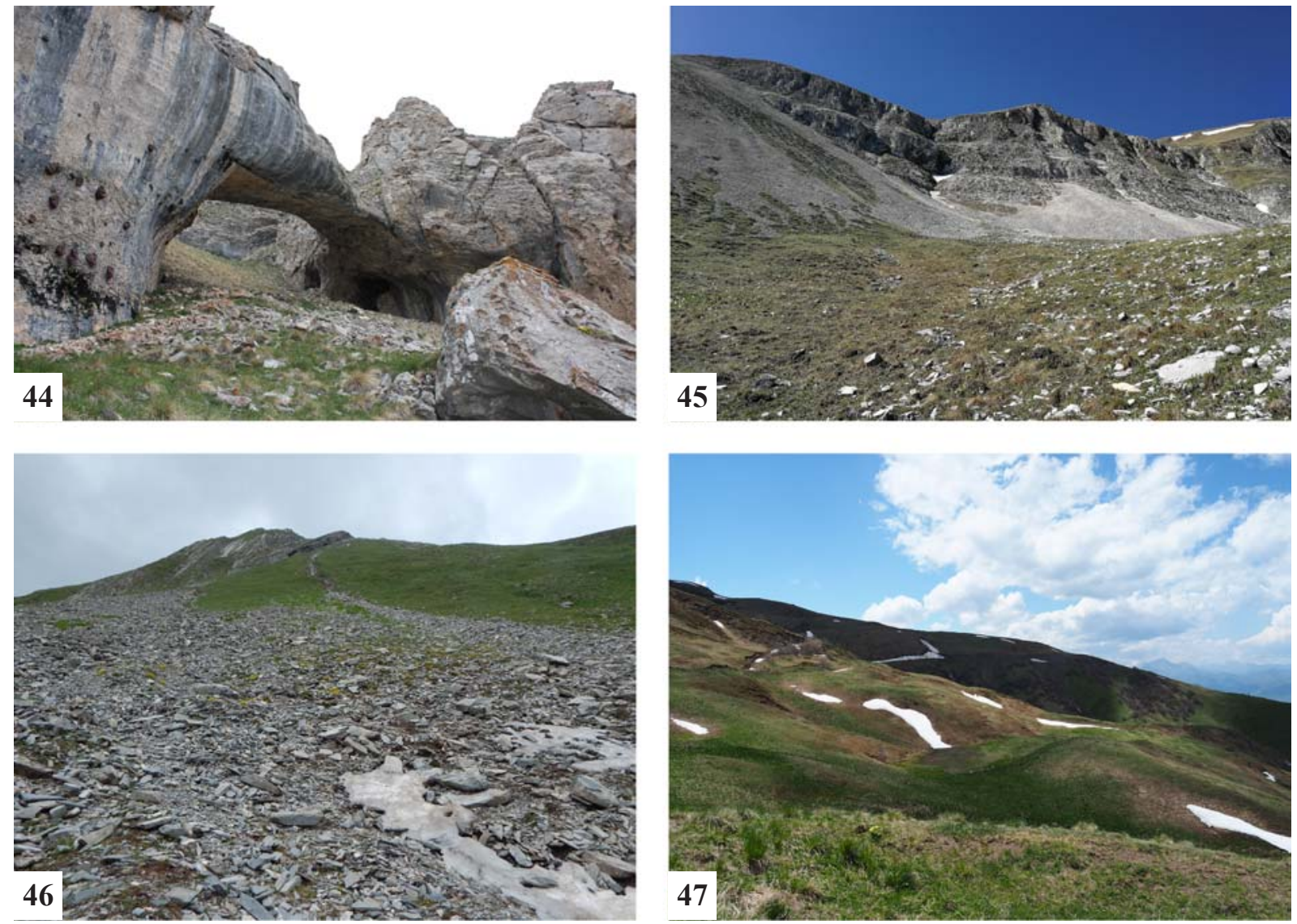

Figs 44-47. Habitats of Mirotribax: $44-$ C. kasakorum tschetschenicus, Mt. Stolovaya, 2800 m.; $45-$ C. nothus daghestanicola, Lake Kazenoy-Am vicinities, 2350 m.; $46-$ C. nothus daghestanicola, Mt. Zainkort, 2800 m.; 47 - C. nothus sharoiensis ssp. n., Sharoy environs, $2400 \mathrm{~m}$.

Рис. 44-47. Местообитания Microtribax: $44-$ C. kasakorum tschetschenicus, г. Столовая, 2800 м над ур. м.; 45 - C. nothus daghestanicola, окр. оз. Казеной-Ам, 2350 м над ур. м.; 46 - C. nothus daghestanicola, г. Заинкорт, 2800 м над ур. м.; $47-$ C. nothus sharoiensis ssp. n., окр. пос. Шарой, 2400 м над ур. м.
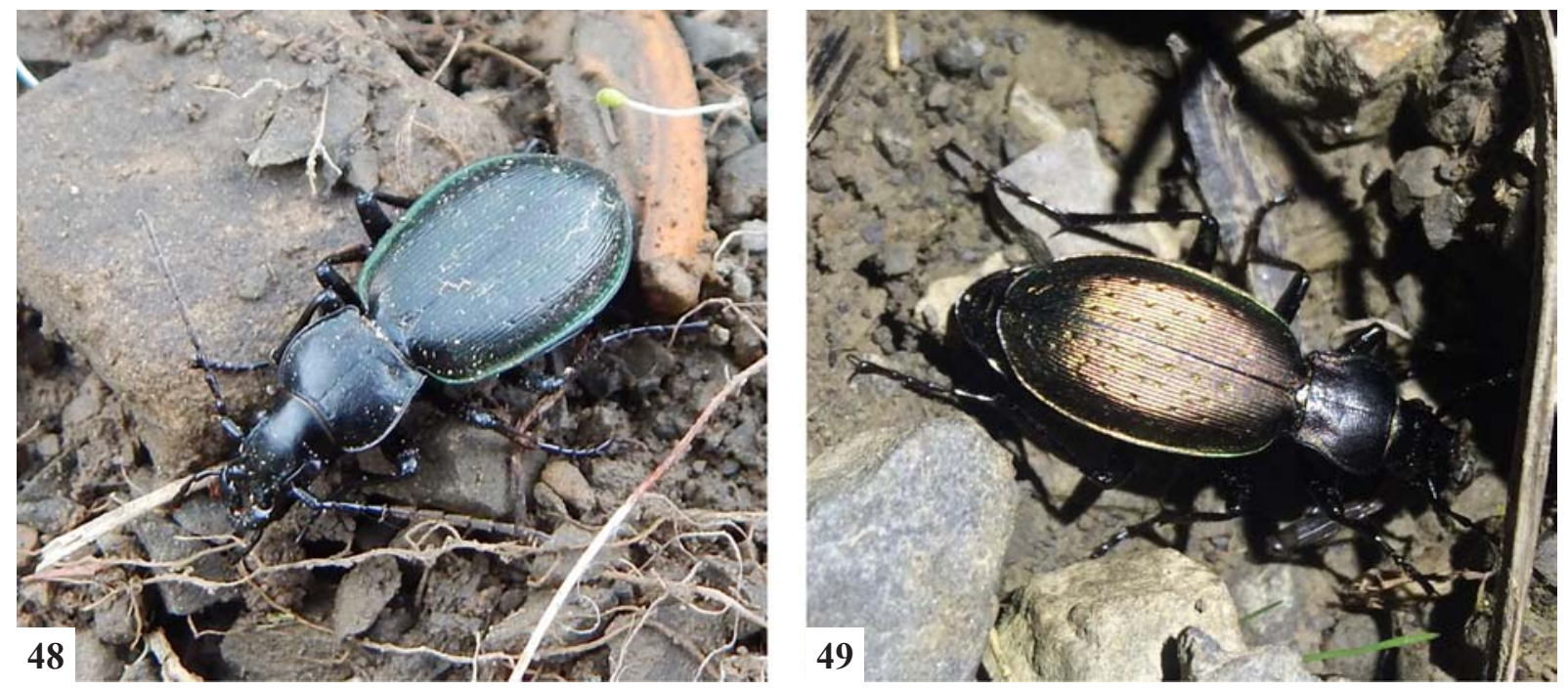

Figs 48-49. Microtribax in nature: $48-$ C. nothus daghestanicola, Mt. Zainkort, 2800 m.; $49-$ C. nothus sharoiensis ssp.n., Sharoy environs, $2400 \mathrm{~m}$.

Рис. 48-49. Microtribax в природе: 48 - C. nothus daghestanicola, г. Заинкорт, 2800 м над ур. м.; 49 - C. nothus sharoiensis ssp.n., окр. пос. Шарой, 2400 м над ур. м. 
carabus) cumanus Fischer von Waldheim, 1823, C. (Megodonthus) exaratus Quensel, 1806, and C. (Procrustes) clypeatus Adams, 1817.

ETYMOLOGY. The subspecific epithet refers to the name Sharoy, indicating both historical geographic and administrative district of Chechen Republic, and one of 9 Chechen tukhums and taips.

\section{Carabus (Microtribax) kasakorum tschetschenicus Semenov, 1896 \\ Figs 1, 7-10, 42, 44.}

Semonov, 1897: 215 (sp. dist.); Breuning, 1935: 11-31 (Tribax); Gottwald, 1980: 33 (Tribax); Kryzhanovskij et al., 1995: 55; Březina, 1999: 55; Bousquet et al., 2003: 169; Deuve, 2004: 263 (Tribax); Retezár, 2015: 91; Březina et al., 2017: 202 (Tribax). ananowi Semonov, 1897: 216 (tschetschenicus var.). scintillans Rapuzzi, 2018: 408 (kasakorum ssp.), syn.n.

MATERIAL. $270^{7} \sigma^{7}, 32$ 우 (CFDD, CTAY, CZAM, CATA), Russia, North Caucasus, Ingushetia, S slopes of Skalistyi Mt. Range near Beyni, $3 \mathrm{~km}$ SE of Mt. Stolovaya, N 42 $500^{\prime} 58.10^{\prime \prime}$, E 4443'49.50", h=2200 m, 22.V-19.VII.2018, D. Fominykh leg.; $840^{7} 0^{7}, 75$ ㅇ (CFDD, CTAY, CZAM, CATA), Ingushetia, S slopes of Skalistyi Mt. Range near Beyni, Mt. Stolovaya, N 4251'35.30",

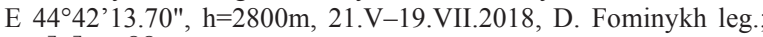
$490^{7} \sigma^{2}, 54$, 99 (CFDD, CTAY, CZAM, CATA), Ingushetia, S slopes of Skalistyi Mt. Range, $5 \mathrm{~km}$ of Mt. Khakhalgi, N 42 50 '10.70", E $45^{\circ} 05^{\prime} 08.50 ", \mathrm{~h}=2500 \mathrm{~m}, 25$.V-19.VII.2018, D.Fominykh leg.; $160^{7} O^{7}, 13$ 우 (CFDD, CTAY, CZAM, CATA), Ingushetia, Skalistyi Mt. Range, $\mathrm{S}$ slopes of Tsoreylam Mt. Range, $5 \mathrm{~km} \mathrm{~W}$ of Mt. Khakhalgi, N 4250'07.60", E $45^{\circ} 05^{\prime} 02.20^{\prime \prime}, \mathrm{h}=2500 \mathrm{~m}, 25$.V21.VII.2017, D. Fominykh, T. Avtaeva, Sh. Kushalieva leg.; $290^{7} 0^{7}$, 26 +9 (CFDD, CTAY, CZAM, CATA), Chechnya, Skalystyi Mt.

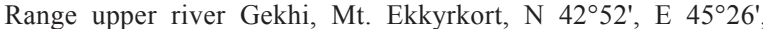
h=2230 m, 26.V-21.VII.2018, D.Fominykh, T. Avtaeva, Sh. Kushalieva leg.; $130^{7} 0^{7}, 17$ 웅 (CFDD, CTAY, CZAM, CATA), Ingushetia, S slopes of Skalistyi Mt. Range near Guli, SE slopes of Mt. Giryag, N 42 $50^{\prime}$, E $44^{\circ} 48^{\prime}, \mathrm{h}=2360 \mathrm{~m}, 25$.V-21.VII.2017, D. Fominykh leg.

REMARKS. This subspecies is known to populate Skalistyi Mt. Range in the interfluve of Terek and Argun rivers, other subspecies of $C$. kasakorum substitute it westwards, $C$. nothus occurs eastwards of Argun valley (Fig. 1). It inhabits alpine zone at 2200-2800 $\mathrm{m}$ and prefers stony hillside wastes, where population density is high, activity of adults starts with the snow melting.

C. kasakorum tschetschenicus is rather variable in body appearance and proportions in different populations (Table $1-2)$, individual populations are variable too, this appears in elytral sculpture intensity, pronotum and elytra proportions, and dorsum luster variations ranging from completely black to bright gold, bronze, or green.

Acknowledgements. The authors are very grateful to $\mathrm{Mr}$. A. Zubov (Kishinev, Moldavia), Mm. Sh. Kushalieva and Mr. M. Taisumov (both Grozny, Russia), for their assistance during the collecting trips to Chechnya and Ingushetia. We are also indebted to Dr. I. Belousov (St. Petersburg, Russia) for providing useful comments on the aforementioned taxa. We wish to acknowledge here also the unselfish help of Prof. Dr. K. Makarov (Moscow, Russia) in taking the photographs and preparing them for publication and help of M.Sc. E. Khomitskiy (Goryachiy Klyuch, Russia) in various technical procedures. Valuable information was reported earlier by the late Prof. Dr. G. Abdurakhmanov. Some aspects of this study were also partially supported by the grant from the Russian Foundation for Basic Research and Administration of Krasnodar Territory (project no 19-44-230004).

\section{References}

Abdurakhmanov G.M. 2009. [A ground beetle of Abdurakhmanov Carabus abdurakhmanovi Belousov] // Krasnaya kniga Respubliki Dagestan. Makhachkala: Ministry for Natural Resources and Nature Conservation of Republic of Dagestan. P.297 [in Russian]

Abdurakhmanov G.M., Davydova M.O. 1999. [Ecological structure and zoogeographic analysis of the ground beetles of the arid hollows of the northeastern part of the Greater Caucasus] // Bioraznoobrazie i zhizn' pochvennykh system. Materialy 2 go (12 go) Vserossiyskogo soveshchaniya po pochvennoy zoologii. Moscow. P.9-10 [in Russian].

Abdurakhmanov G.M., Gayrabekova R.Kh., Kushalieva Sh.A. 2007. [A ground beetle of Abdurakhmanov] // Krasnaya kniga Chechenskoy Respubliki. Redkie i nakhodyashchiesya pod ugrozoy ischeznoveniya vidy rasteniy i zhivotnykh. Grozny: Government Committee of Chechen Republic for Ecology. P.198 [in Russian].

Abdurakhmanov V.G. 2012. [Zoogeographic characteristics and spatial distribution of the ground beetles genus Carabus (Coleoptera, Carabidae) of the Main Caucasian Range] // Materialy XIV Mezhdunarodnoy konferenzii "Biologicheskoye raznoobraziye Kavkaza i Yuga Rossii”, posviashchennoy 70 letiyu so dnia rozhdeniya Gayirbega Magomedovicha Abdurakhmanova (Makhachkala, 57 noyabria 2012 g.). Makhachkala: Institute of the Problems of Ecology of Republic of Dagestan. P. 101-103 [in Russian].

Avtaeva T.A., Kushalieva Sh.A. 2017. New data on ground beetles (Coleoptera, Carabidae) of the mountain areas of the Chechen Republic // Vestnik Moskovskogo gosudarstvennogo oblastnogo universiteta. Seriya: Estestvennye nauki. No.4. P.614 [in Russian]. doi: 10.18384/2310718920174614.

Bousquet Y., Březina B., Davies A., Farkač J., Smetana A. 2003. Tribe Carabini Latreille, 1802 // I. Löbl, A. Smetana (eds.). Catalogue of Palaearctic Coleoptera. Vol.1. ArchostemataMyxophaga-Adephaga. Stenstrup: Apollo Books. P.118-201.

Breuning S. 1935. Monographie der Gattung Carabus L. (VI. Teil) // Bestimmungs-Tabellen der europaischen Coleopteren. Hf.109. Troppau: Edmund Reitter's Nachf. Emmerich Reitter. S.11231360.

Březina B. 1999. World Catalogue of the Genus Carabus L. SofiaMoscow: Pensoft Publishers. 170 pp.

Březina B., Huber C., Marggi W. 2017. Subtribe Carabina Latreille, 1802 // I. Löbl, D. Löbl (eds.). Catalogue of Palaearctic Coleoptera. Revised and Updated Revision. Vol. 1, ArchostemataMyxophaga-Adephaga. Lieden-Boston: Brill. P.70-207.

Deuve Th. 2004. Illustrated catalogue of the genus Carabus of the World (Coleoptera: Carabidae). Sofia-Moscow: Pensoft Publishers. $461 \mathrm{pp}$

Erzhapova R.S. 2012. [Ground beetles Coleoptera Carabidae, listed in the Red Data Book of Chechen Republic] // Materialy XIV Mezhdunarodnoy konferenzii "Biologicheskoye raznoobraziye Kavkaza i Yuga Rossii”, posviashchennoy 70-letiyu so dnia rozhdeniya Gayirbega Magomedovicha Abdurakhmanova (Makhachkala, 57 noyabria 2012 g.). Makhachkala: Institute of the Problems of Ecology of Republic of Dagestan. P. 105-107 [in Russian].

Fominykh D.D., Zamotajlov A.S. 2017. [Contribution to the knowledge of the ground beetles genus Carabus L. (Coleoptera, Carabidae) in the Caucasus] // Materialy XIX Mezhdunarodnoy konferenzii s elementami nauchnoy shkoly molodykh uchenykh "Biologicheskoye raznoobraziye Kavkaza i Yuga Rossii", posviashchennoy 75 letiyu so dnia rozhdeniya doktora biologicheskikh nauk, zasluzhennogo deyatelya nauki Rossii, akademika Rossiyskoy ekologicheskoy akademii, professora Gayirbega Magomedovicha Abdurakhmanova (Makhachkala, 47 noyabria 2017 g.). T.2. Makhachkala: Institute of the Problems of Ecology of Republic of Dagestan. P. 525-529 [in Russian].

Fominykh D.D., Zamotajlov A.S., Titarenko A.Yu. 2016. Further contribution to the knowledge of Georgian species of the Carabus Linnaeus, 1758 subgenus Neoplectes Reitter, 1885, with 
The subgenus Microtribax in the North Caucasus

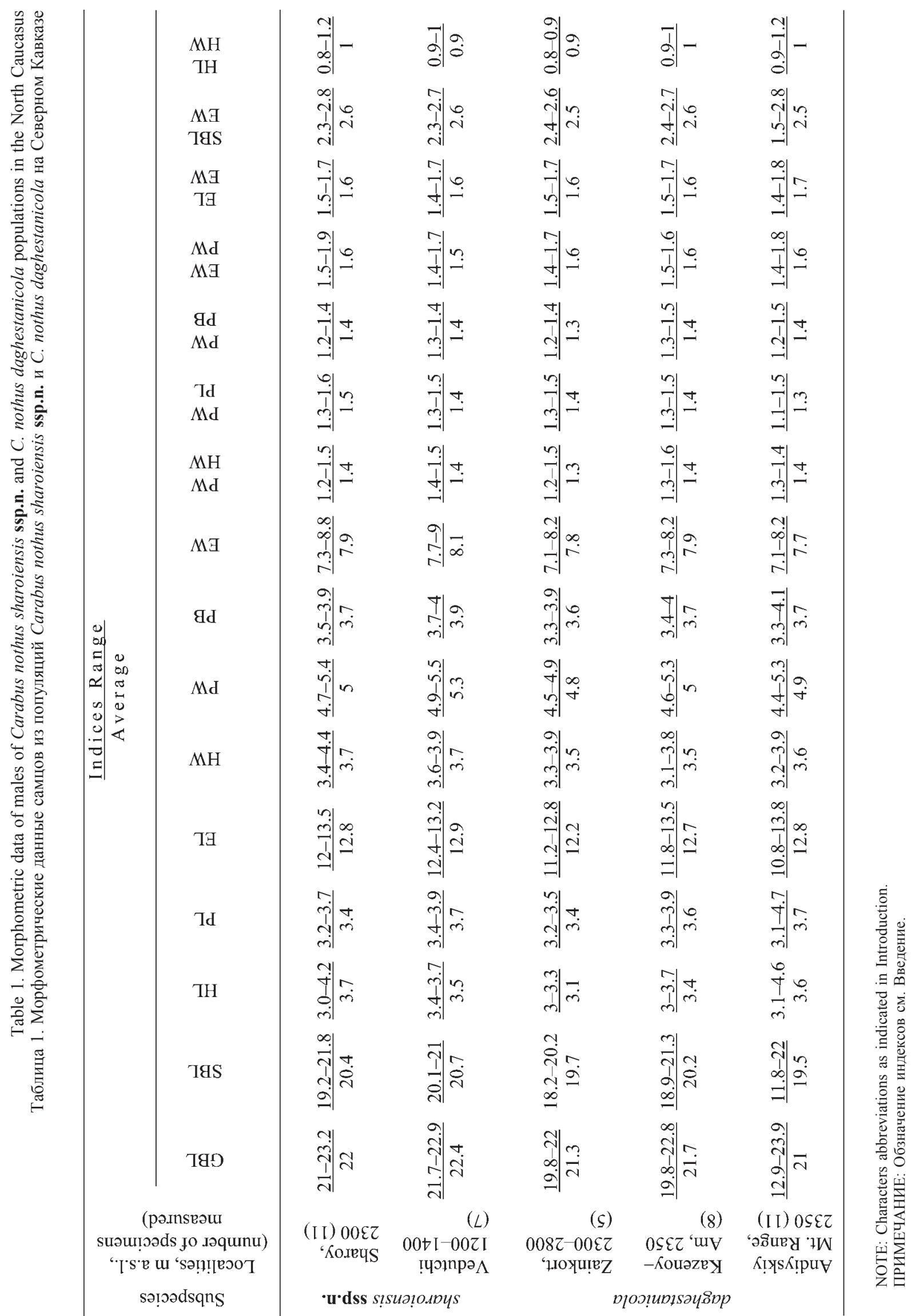




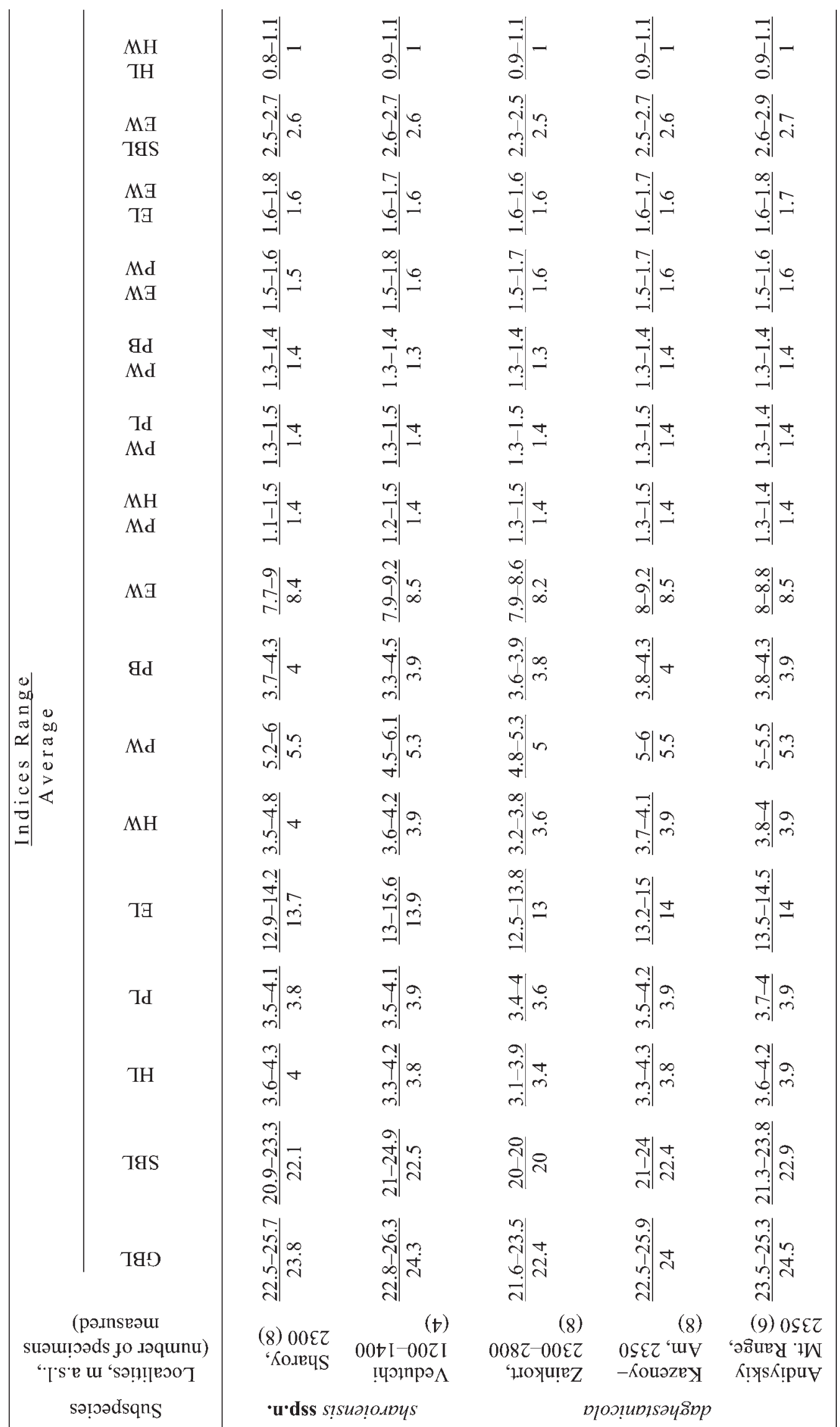


description of a new subspecies of $C$. titarenkoi Zamotajlov \& Fominykh, 2014 (Coleoptera: Carabidae: Carabini) // Zootaxa. Vol.4179. No.3. P.561-599. doi: 10.11646/zootaxa.4179.3.10.

Gottwald J. 1980. Revision der Untergattung Tribax der Gattung Carabus (Coleoptera, Carabidae) // Acta ent. bohemoslov. Vol.77. P.25-45.

Gottwald J. 1982. Zur Taxonomie und Nomenklatur von Tribax und verwandten Untergattungen der Gattung Carabus // Acta ent. bohemoslov. Vol.79. P.207-220.

Huber C., Löbl I., Marggi W. 2017. Carabidae: Carabini: Carabus // I. Löbl, D. Löbl (eds.). Catalogue of Palaearctic Coleoptera. Revised and Updated Revision. Vol.1. Archostemata-Myxophaga-Adephaga. Lieden-Boston: Brill. P.23. [New nomenclatural and taxonomic acts, and comments].

Janovska M., Anichtchenko A.V., Erwin T. 2013. Significant new taxonomic tool for Carabidae (Insecta: Coleoptera): endophallus inflation methods revised // Caucasian Entomological Bulletin. Vol.9. No.1. P.39-42.

Kryzhanovskij O.L., Belousov I.A., Kabak I.I., Kataev B.M., Makarov K.V., Shilenkov V.G. 1995. A checklist of the ground-beetles of Russia and adjacent lands. Sofia-Moscow: Pensoft Publishers. $271 \mathrm{pp}$.
Makarov K.V., Kryzhanoskiy O.L., Belousov I.A., Zamotajlov A.S.,Kabak I.I., Kataev B.M., Shilenkov V.G., Matalin A.V., Fedorenko D.N. 2013. Taxonomical list of ground beetles (Carabidae) of Russia. Available from: https://www.zin.ru/Animalia/Coleoptera/eng/car_rus.htm. [Accessed April 9, 2018].

Osawa S., Su Z.-H., Imura Y. 2004. Molecular phylogeny and evolution of carabid ground beetles. Tokyo: Springer Japan. 191 pp. doi: 10.1007/9784431539650.

Rapuzzi I. 2018. New Carabus Linnaeus, 1758 (Coleoptera Carabidae) from Caucasus and China. Description of the male of Carabus (Apotomopterus) ebian Cavazzuti et Rapuzzi, 2010 // Biodiversity Journal. Vol.9. No.4. P.405-410. doi: 10.31396/ Biodiv.J.2018.9.4.405.410.

Retezár I. 2015. Atlas of the Carabus of the Caucasus (Coleoptera, Carabidae). Iconography, genital morphology, systematics and faunistics. Budapest: Szerzõi kiadás, Mondat Kft. 134 pp. 79 maps. 238 color plates.

Semenov A.P. 1897. Symbolae ad cognitionem generis Carabus (L.) A. Mor. I. // Horae Societatis Entomologicae Rossicae. T.30. P.193-229.

Shilenkov V.G. 1996. [The ground beetles of the genus Carabus L. (Coleoptera, Carabidae) of South Siberia]. Irkutsk: Irkutsk State University Publ. 80 pp. [In Russian] 